DOI: 10.46340/ephd.2021.7.2.3

Mykyta Marienko

ORCID ID: https://orcid.org/0000-0003-4299-4165

V. N. Karazin Kharkiv National University, Ukraine

\title{
SECONDS IN THE RUSSIAN EMPIRE: LEGAL, ETHICAL AND FUNCTIONAL STATUS
}

\author{
Микита Мар'єнко \\ Харківський національний університет імені В. Н. Каразіна, Україна
}

\section{СЕКУНДАНТИ В РОСІЙСЬКІЙ ІМПЕРІЇ: ПРАВОВИЙ, ЕТИЧНИЙ І ФУНКЦІОНАЛЬНИЙ СТАТУС}

\begin{abstract}
The article is devoted to the definition of the legal, ethical and functional status of seconds in the Russian Empire. With the appearance of legislative regulations governing legal responsibility for participating in a duel in Russia of Peter the Great, the duelists, and with them their seconds, became subjects of criminal procedure. It was fixed in several documents: in Artikul voinskiy (Military regulations) (1715), Patent o poedinkah i nachinanii ssor (Duels and quarrels patent) (1716), Manifest o poedinkah (Duels manifesto) and in the chapter "O poedinkah" (About duels) of Ulozhenie o nakazaniyah (Code about punishments) (1845). Being punished together with the direct participants in the duel, the seconds risked their own freedom for other people's interests. During duel encounters, the seconds acted as judges of the opponents, that, as a rule, testified to their high moral qualities and knowledge of the ritual side of the duel. Nevertheless, some sources also recorded cases of abuse of seconds by their duties. In such cases, they were subjected to more severe punishment than the duelists. Pravila o razbiratelstve ssor, sluchayuschihsya $v$ ofitserskoy srede (The rules of solving disputes taking place in the officer's environment) (1894) radically changed the dueling legislation. Since then, the right to appoint a duel in a particular conflict situation has come to belong to the Court of the Society of Officers. The seconds thus have lost an essential part of their functions. The new dueling decree was expected only for representatives of the officer community, which caused additional conflicts between them and civilians. The manifestation of this conflict was the "struggle" for the creation of a dueling code, and the result was the emergence of two dueling codes that were widely used in the civilian environment. In the dueling codes, which appeared at the beginning of the 20th century, for the first time the rules of a duel, including the functions of seconds, were regulated. In conclusion, the fruitfulness of studying the activities of seconds for a deeper understanding of the phenomenon of duel is noted.

Keywords: duel, dueling legislation, dueling codes, seconds, Russian Empire.
\end{abstract}

За визначенням Ю. М. Лотмана, «дуэль» (поединок) - происходящий по определённым правилам парный бой, имеющий целью восстановление чести, снятие с обиженного позорного пятна, нанесённого оскорблением» ${ }^{1}$. Важливою частиною дуельних правил була присутність секундантів під час поєдинку, які виступали в ролі суддів суперників у процесі зіткнення.

У перших двох нормативних документах, у яких йшлося про поєдинки в Росії, в «О нечинении иноземцам никаких между собою ссор и поединков, под смертною казнию» 1702 р. та в «Уложении Шереметева» 1702 р., секунданти не згадувались. Але вже у 1706 р., в «Кратком артикуле Меньшикова», законодавець вперше звертає свій погляд на секундантів, які поки визначаються як «свідки». Зокрема, в цьому документі говорилось про таке бажання законодавця, щоб секунданти прагнули до примирення суперників, а в разі невдачі повідомляли про дуель на вартуㄹ․

\footnotetext{
1 Лотман, Ю. М. (2011). Беседы о русской культуре: Быт и традииии русского дворянства (ХVIII-начало ХІХ века). Санкт-Петербург: Искусство-СПБ, 164.

2 Див. за Шендзиковский, И. А. (1885). Конспект лекций по истории русского военно-уголовного законодательства. Санкт-Петербург, 40.
} 
Варто сказати, що «Краткий артикул Меньшикова» не був затверджений Петром I, i мав тимчасовий характер.

Найбільш докладно відношення законодавця до поєдинків у петровську добу було відображено в «Артикуле воинском» 1715 р. і в «Патенте о поединках и начинании ссор» 1716 р. У 140-му артикулі першого документу вказувалось, що секунданти (також їх називали «посредственниками») повинні отримувати таке ж покарання, як і дуелянти ${ }^{1}$. А покарання було максимально суворим: «... как вызыватель, так и кто выйдет, имеет быть казнен, а именно повешен, хотя из них кто будет ранен или умерщвлен, или хотя оба не ранены от того отойдут» ${ }^{2}$ Більш змістовно про покарання учасників поєдинків йшлося в «Патенте о поединках и начинании ссор». За сам факт домовленості про дуель для секундантів (тут їх вже називали «посредниками») передбачалось наступне покарання: «... от всех своих чинов и достоинств отставлен, и наперед за негодного объявлен, а потом по имению его денежный штраф взять и по состоянию дел десятая, шестая, а по крайней мере третья часть имения его отписана имеет быть» ${ }^{3}$. В разі, якщо справа доходила безпосередньо до дуелі, то всім учасникам події призначалась смертна кара ${ }^{4}$, однак був i один виняток: якщо супротивники самостійно приймали рішення припинити бій, то й вони, й секунданти були зобов'язані лише сплатити «жестокий штраф» 5 .

Таким чином, за петровської доби за участь у поєдинку (як у якості дуелянта, так і в якості секунданта) передбачались жорстокі міри покарання. Однак варто мати на увазі, що поєдинки у той час відбувались нечасто (відомо лише про три дуелі в ці роки) і не карались настільки суворо, як це передбачалось законом. Ці обставини дозволяють вважати слова прусського дипломата I. Фоккеродта цілком справедливими: «... Петр 1-й ни при одном своем Указе не нашел такой покорности, как при запрещении поединков, да и по сю пору никто из Русских Офицеров не подумает требовать удовлетворения в случае безчестия, нанесенного ему равным лицом, а строго следует предписанию Указа о поединках, повелевающего оскорбленной стороне подавать в подобных обстоятельствах жалобу, а потом виноватому всенародно просить у него прощения и восстановить его честное имя...» ${ }^{6}$.

Наступна зміна дуельного законодавства була пов'язана 3 появою у 1787 р. «Манифеста о поединках» Катерини II. У жодному іншому документі не приділялось так багато уваги секундантам (у цьому указі їх також визначали як «посредников», «примирителей», «подмогателей», «надежных»). Нова дуельна постанова містила в собі певне сподівання, що секунданти зможуть стати серйозним важелем впливу на дуелянтів, для чого законодавець навіть наділив їх відповідними повноваженнями: «... и для того посреднику и надежным дается власть, ссорящимся, именем закона, запретить драку» ${ }^{7}$. У законі також вказувалось, що «примирителя и посредников первый долг есть прекратить ссоры и распри и восстановить мир и тишину» ${ }^{8}$, а за відмову супротивників битись без свідків «Манифест о поединках» передбачав окреме покарання для дуелянтів ${ }^{9}$, що також підтверджує примирливий статус, який надавав законодавець секундантам. Проте у випадку, якщо секундантам не вдавалось примирити суперників, вони отримували покарання вже як учасники і винуватці дуелі ${ }^{10}$. Указ о дуэлях 1787 р., який діяв до 1845 р., вважався найгуманнішим серед відповідних європейських законів ${ }^{11}$, але його значення обмежується, перш за все, осмисленням дуелі та проблем захисту особистої честі як такої.

За катерининської доби, не дивлячись на більш м'яке ставлення законодавця до поєдинку, ніж у петровський час, у джерелах фіксувалась вірогідність покарання за участь у дуелі. У цьому відношенні показовими є два приклади.

\footnotetext{
${ }^{1}$ Артикул воинский (1986). Российское законодательство X-ХХ веков. Москва: Юридическая литература, $4,353$.

2 Там само.

${ }^{3}$ Патент о поединках и начинании ссор (1830). Полное собрание законов Российской империи. Собр. 1-е. Санкт-Петербург, 5, 263.

${ }^{4}$ Там само.

5 Там само.

${ }^{6}$ Фоккеродт, И. Г. (1874). Россия при Петре Великом. Москва, 109-110.

${ }^{7}$ Манифест о поединках (1830). Полное собрание законов Российской империи. Собр. 1-е. Санкт-Петербург, $22,843$.

${ }^{8}$ Там само, 844 .

9 Там само, 845 .

${ }^{10}$ Там само, 844

11 Ливенсон (1900). Поединок в законодательстве и науке. Санкт-Петербург, 22.
} 
У 1777 р. відбувся поєдинок між О. Храповицьким, майбутнім секретарем Катерини II (i, до речі, автором записок про імператрицю, які містять також інформацію про роботу над «Манифестом о поединках»), та Окуневим, секундантом якого був поет і відомий державний діяч Г. Державін. Спочатку секунданти змогли примирити суперників, але пізніше Хвостов, секундант О. Храповицького, сказав, «что должно было хотя немножко поцарапаться, дабы не было стыдно» (до речі, Г. Державін уважав, що «никакого в том нет стыда, когда без бою помирились») ${ }^{1}$. Зрештою суперники все ж таки «обнажили шпаги и стали в позитуру, будучи по пояс в снегу», і лише після цього секундантам вдалось остаточно переконати дуелянтів припинити поєдинок. Після цього всі учасники «зашли в трактир, выпили по чашке чаю, а охотники - пуншу, кончили страшную войну с обоюдным триумфом» 2 . Цікаві роздуми Г. Державіна про ймовірні наслідки участі як секунданта в дуелі проти О. Храповицького, соціальне положення якого на той час було вже доволі значним: «Что делать? С одной стороны короткая приязнь препятствовала от сего посредничества отказаться, с другой соперничество против любимца главного своего начальника, к которому едва только стал входить в милость, ввергало его [у своїх «Записках» Г. Державін пише про себе в третій особі. - М. М.] в сильное недоумение» ${ }^{3}$. Для того аби позбавитися цих сумнівів, Г. Державін вирішив порадитися зі своїм начальником обер-прокурором I. Резановим. Не зустрівши I. Резанова вдома, Г. Державін вирушив на його пошуки за іншою адресою, де разом зі своїм начальником зустрів і свою майбутню дружину. Поет був настільки зачарований нею, що забув про причину свого візиту до будинку Л. Тредіяковського, де й відбувалася ця зустріч ${ }^{4}$. Важливо, що його страхи стосувалися не закону, а, імовірніше, гніву начальника. Власне, гнів начальника міг призвести до кримінального покарання. Слова I. Долгорукова «... законы и у нас подобны, как некогда сказал мудрый Солон, паутине, в которую попадает комар, а крупная муха сама её прорывает» ${ }^{5}$ точно характеризують зображену ситуацію.

У 1785 р. відбулася дуель між Г. Ржевським та Даниловим. Ось як про цю подію писав I. Долгоруков, секундант першого: «Погода была прекрасная, и молодые мальчики, вместо того, чтобы съехаться в сад наслаждаться природой, условились тут же резаться и поливать зелень своей кровью. Прекрасная забава», «... Увидели мы кровь, и, по условию, тотчас прекратили драку. Поединщики поцеловались. Новое дурачество, и совсем ненатуральное! Я же обижен, я же ранен, и цалуй соперника. Какое превратное понятие о сердце оскорблённом!» ${ }^{6}$. Але сам мемуарист добре розумів, що й дуелянтів, і секундантів цілком може бути покарано: «Тогда подобные проказы наказывались, ещё и довольно строго. Я не мог отказаться от сей услуги Ржевскому, несмотря на все опасности, потому что в близком был с ним свойстве, да и жили вместе» ${ }^{7}$.

«Золотим століттям» дуелі в Російській імперії справедливо прийнято вважати XIX ст.: саме в цей період поєдинки стали доволі поширеною формою захисту особистої честі. При цьому відношення правителів до дуелі було різним. Роки правління Олександра I характеризувалися м'яким відношенням до поєдинків. Ось що з приводу цього писав відомий декабрист С. Волконський: «... в царствование Александра Павловича дуэли, когда при оных соблюдаемы были полные правила общепринятых условий, не были преследуемы Государем, а только тогда обращали на себя взыскание, когда сие не было соблюдено, или вызов был придиркой так называемых bretteurs; и то не преследовали таковых законом, а отсылали на Кавказ. Дуэль почиталась Государем, как горькая необходимость в условиях общественных» ${ }^{8}$.

Більш суворо відносились до учасників поєдинків у роки правління Миколи I та Олександра II. Показово, що в цей час саме секунданти у деяких випадках отримували більш суворе покарання, аніж дуелянти. Зокрема, жорстоке покарання отримав корнет Алі-Гассан за дуель, у якій його суперниками були поручик Зинов'єв і корнет Кошкін, якого було вбито на поєдинку (1840-ві рр.). Показово, що за конфірмацією імператора той, хто вбив свого товариша по службі, залишився зовсім безкарним,

\footnotetext{
${ }^{1}$ Державин, Г. Р. (1871). Записки. Сочинения Державина с объяснительными примечаниями Я. Грота. Санкт-Петербург, 6, 541.

2 Там само, 541-542.

3 Там само, 540.

4 Там само.

5 Долгоруков, И. М. (2004). Повесть о рождении моем, происхождении и всей жизни. Санкт-Петербург: Наука, $1,368$.

6 Там само, 108.

7 Долгоруков, И. М. (1997). Капище моего сердиа. Москва: Наука, 108.

8 Записки Сергея Григорьевича Волконского (декабриста). (1901). Санкт-Петербург, 63-64.
} 
одного із секундантів на місяць ув'язнили у фортеці, а от другому секунданту, Алі-Гассану, було призначене таке покарання: «... по лишению всех прав состояния сослать на двадцать лет в каторжную работу в сибирские рудники». Настільки сувора міра була мотивована тим, що АліГассан, по-перше, посварив майбутніх дуелянтів, а по-друге, як секундант, зробив все залежне від нього для того, аби завадити примиренню Кошкіна та Зинов'єва ${ }^{1}$. У 1842 р. на поєдинку проти Ерасі був убитий Меллер-Закомельський. Цікаво, що й у цій історії вбивця фактично залишився безкарним, лише був відправлений на 8 місяців на покаяння до монастиря. Це обумовлювалося тим, що Ерасі був змушений прийняти виклик Меллер-Закомельського. Зате Нікітіну, одному із секундантів, було призначено чотиримісячне ув'язнення у фортеці, а Мамонтов, який сприяв проведенню поєдинку, був розжалуваний у солдати й переведений в інший полк ${ }^{2}$. Як бачимо, настільки сувору кару секунданти отримували лише в окремих випадках. Тоді, коли вони не порушували принципи честі, покарання були м'якішими. Так, К. Данзас, секундант О. Пушкіна, був витриманий на гауптвахті у фортеці протягом двох місяців ${ }^{3}$, а князь О. Васильчиков та М. Глєбов, секунданти М. Лермонтова та М. Мартинова, були повністю помилувані: «... князя Васильчикова и корнета Глебова простить, первого во внимание к заслугам отца, а второго по уважению полученной тяжелой раны» ${ }^{4}$

Приблизно до цього ж часу (1840р.) відноситься джерело, яке варто вважати свого роду унікальним. Так, після першої дуелі М. Лермонтова проти Е. де Баранта, секундант поета О. Столипін написав лист голові Третього Відділення О. Бенкендорфу, в якому містились наступні слова: «... несколько дней тому назад узнав, что Лермонтов арестован и предполагая, что он найдет неприличным объявить были ли при дуэли его секунданты и кто именно, я долгом почел в то же время явиться к начальнику штаба вверенного Вашему сиятельству корпуса и донести ему о моем соучастничестве в этом деле. До ныне однако я остаюсь без объяснений. Может быть генерал Дубельт не доложил о том Вашему сиятельству, или быть может и Вы, граф, по доброте души своей умалчиваете о моей вине. Терзаясь за тем мыслию, что Лермонтов будет наказан, а я, разделявший его поступок, буду оставлен угрызениям моей совести - спешу по долгу русского дворянина принести Вашему сиятельству свою повинную.... ${ }^{5}$. Можна стверджувати, що у процитованому документі відображено секундантську етику російського дворянина першої половини XIX ст.

У 1845 р. відбулася ще одна зміна правового статусу дуелі, зафіксована в розділі «О поединках» Уложения о наказаниях. У новій дуельній постанові, зокрема, знайшли відображення загальні тенденції до лібералізації кримінального законодавства, важливим проявом яких було «уменьшение доли наказаний, направленных против здоровья осуждённого за счёт увеличения количества наказаний по ограничению свободы» ${ }^{6}$ У цьому документі приділялась увага й секундантам. Зокрема, вказувалось, що за невиконання секундантами усіх можливостей для запобігання поєдинкуув'язнення в фортеці терміном від шести місяців до одного року ${ }^{7}$, а за підбурення з їхнього боку до дуелі - ув'язнення в фортеці терміном від чотирьох до шести років ${ }^{8}$.

У роки правління Олександра II, в цілому, зберігалось помірковано суворе ставлення як до дуелянтів, так і до секундантів. У 1859 р. за вбивство на дуелі прапорщика Шелухіна засудили його суперника підпоручика Грицко, а також секундантів Римського-Корсакова й Крузенштерна. Імператор визначив таке покарання: «подсудимого подпоручика Грицко разжаловать в рядовые без лишения дворянства, а секундантов выдержать в крепости один месяц» ${ }^{9}$. Показова історія дуелі між поручиком Д. Певцовим та корнетом Бієльським, вбитим під час поєдинку (1860р.). Княгиня Гагаріна, мати одного із секундантів, клопотала про помилування свого сина через підготовку селянської реформи й потреби його присутності в маєтку. Водночас ії аргументація свідчила про належний рівень освіченості про останні поєдинки, що, вочевидь, натякає на ії близькість до високопоставлених діячів. Результатом цього клопотання для Гагаріна стала заміна тримісячного

\footnotetext{
${ }^{1}$ Марков, А. Л. (1999). Поединки в русской армии. Новый часовой. Русский военно-исторический журнал, 8-9, 234.

2 Русская старина (1908). Дуэль Эраси с Меллером-Закомельским (Из воспоминаний старого гусара), 134, 598-603.

3 Дуэль Пушкина с Дантесом-Геккереном. Подлинное военно-судное дело 1837 года. (1900). Санкт-Петербург, 145.

${ }^{4}$ Цит. за Лермонтовская эничиклопедия (1981). Москва: Советская энциклопедия, 154.

5 Державний архів Російської Федерації, ф. 109, оn. 180, спр. 104, арк. 1.

${ }^{6}$ Ружицкая, И. В. (2015). Законодательная деятельность в иарствование императора Николая I. Москва;

Санкт-Петербург: Институт российской истории РАН; Центр гуманитарных инициатив, 262.

7 Уложение о наказаниях уголовных и исправительных (1845). Санкт-Петербург, 770.

${ }^{8}$ Уложение о наказаниях уголовных и исправительных (1845). Санкт-Петербург, 771.

${ }^{9}$ Русские уголовные процессы (1867). Санкт-Петербург, 2, 63-64.
} 
ув'язнення в тюрмі на рік домашнього арешту. Певцову через кілька місяців утримання в Шліссельбурзькій фортеці Олександром II було дароване прощення ${ }^{1}$. Однакова міра покарання була призначена як для Лисикевича, який убив на дуелі Адамовича, так і для секундантів - Войнаровича й Калеміна. Це було спричинено поведінкою учасників події після пострілу, «так как со стороны их не только не было принято никаких мер предосторожности для подания немедленной помощи раненому Адамовичу, но они бросили последнего на месте поединка, не распорядясь об оказании ему медицинского пособия под тем предлогом, что он был убит, между тем как он был найден еще живым, спустя довольно продолжительное время, и был привезен в госпиталь, умер уже там по истечении двух часов, причем смерть его, по заключения медика, последовала между прочим от значительного истечения крови». Лисикевич, Войнарович і Калемін були позбавлені дворянства, розжалувані в рядові й піддані церковному покаянню2 ${ }^{2}$ Ці приклади можна продовжувати.

У 1894 р. відбулась остання, й при цьому найбільш радикальна, зміна дуельного законодавства. Тоді були опубліковані «Правила о разбирательстве ссор, случающихся в офицерской среде», згідно з якими право розглядати «конфликты чести» і в тій чи іншій ситуації призначати поєдинки стало належати Суду товариства офіцерів. Нова постанова торкнулась і правового статусу секундантів: «Когда поссорившиеся, согласно определению Суда, решат окончить ссору поединком, Суд общества офицеров употребляет свое влияние на секундантов в том смысле, чтобы условия дуэли наиболее соответствовали обстоятельствам данного случая» ${ }^{3}$. Таким чином, порушувались як приватний характер дуелі в Російській імперії, так і широкі повноваження секундантів, які раніше самостійно «керували» поєдинком. Однак новий указ поширювався на представників офіцерського середовища, в той час як всі інші, відповідно до Уложения о наказаниях 1885 р. (з якими, до речі, не були узгоджені «Правила о разбирательстве ссор, случающихся в офицерской среде») досі отримували покарання за дуель. Ця ситуація призводила до додаткових конфліктів між цивільними особами i представниками офіцерського товариства ${ }^{4}$. Своєрідним проявом цього конфлікту стала «боротьба» за створення дуельного кодексу ${ }^{5}$. Підсумком «протистояння», яке склалося, стало створення кількох дуельних кодексів, які використовувались у цивільному середовищі. Найбільш відомими з них стали «Дуэльный кодекс» В. Дурасова и «Дуэльный кодекс» О. Суворіна. Варто зазначити, що в цих текстах вперше в Російській імперії були регламентовані правила дуелі. До того основними джерелами керівництва для поєдинків були дуельна традиція та поговір, закордонні дуельні кодекси і художня література. У працях В. Дурасова та О. Суворіна міститься й важлива інформація щодо секундантів. Так, перший повідомляє про обов'язкові моральні якості секунданта (чесність, неупередженість), їх обов'язки (до їх довірителя; відносно протилежної сторони; відносно один одного; під час переговорів), правила проведення поєдинку та особливості складання протоколу ${ }^{6}$, а другий - про призначення секундантів, їхні обов'язки, повноваження та діяльність ${ }^{7}$. Ці дані дозволяють оцінити масштаб специфічних знань, здібностей і певних особистих якостей секундантів, необхідних для проведення поєдинку в суворій відповідності з дуельними правилами. Дуельні кодекси В. Дурасова та О. Суворіна представляють цінні джерела для уявлень про семіотичні механізми дуелі, й з цього боку вони потребують серйозного наукового осмислення.

Особа секунданта в джерелах, які розповідають про дуелі, відтінена причинами й обставинами поєдинку, особистостями дуелянтів, характером слідства. Це зрозуміло, хоч і не зовсім справедливо. Разом із дуелянтами вони піддавались кримінальному переслідуванню, ризикуючи своєю свободою заради чужих інтересів. Секунданти брали на себе відповідальність за життя інших навіть тоді, коли конфлікт був викликаний непорозумінням. I навпаки - вони мирили суперників у тих ситуаціях, коли, здавалося б, дуель неминуча. I, нарешті, секунданти були втіленням уявлень про особисту честь. Саме таким можна вважати ідеальний образ секунданта. Реальна практика поєдинків показує, що визначені

\footnotetext{
${ }^{1}$ Державний архів Російської Федерації, ф. 109, on. 200, сnр. 229, арк. 13-35.

${ }^{2}$ Русские уголовныле процессы (1866). Санкт-Петербург, 1, 576-577.

${ }^{3}$ Правила о разбирательстве ссор, случающихся в офицерской среде. (1898). Полное собрание законов в Российской империи. Собр. 3-е. Санкт-Петербург, 14, 257-258.

4 Зайончковский, П. А. Самодержавие и русская армия на рубеже ХІХ-ХХ столетий. (1973). Москва: Мысль, 245.

5 Див. Марьенко, Н. Ю. Правила о разбирательстве ссор, случающихся в офицерской среде: значение и последствия изменения дуэльного законодательства в 1894 г. (2019). Вісник Харківського національного університету. Серія Історія, 56, 81-82.

6 Дурасов, В. (1912). Дуэльный кодекс. Санкт-Петербург, 39; 46-53.

${ }^{7}$ Суворин, А. (1913). Дуэльный кодекс. Санкт-Петербург, 54-78.
} 
принципи були характерні не для всіх секундантів, однак нечисленні негативні приклади не дозволяють зробити загальний висновок про систематичне недотримання секундантами дуельних правил, навіть не дивлячись на «зусилля» художньої літератури XIX ст., де значна частина поєдинків проходить з їх порушенням - вочевидь, ці порушення використовувались авторами певною мірою не без наміру.

Так чи інакше, секундантів необхідно вважати важливою частиною історії дуелей. Погляд на той чи інший дуельний епізод не лише з боку дуелянтів або влади, а й з боку секундантів може бути плідним для осмислення феномену дуелі в Російській імперії.

\section{References:}

1. Artikul voinskiy [Military article] (1986). Rossiyskoye zakonodatelstvo X-XX vekov [Russian legislation of the X-XX centuries]. Moscow: Legal Literature, 4, 353. [in Russian].

2. Derzhavin, G. R. (1871). Zapiski. Sochineniya Derzhavina s obyasnitelnymi primechaniyami Y. A. Grota [Notes. Works of Derzhavin with explanatory notes by J. Grot]. St. Petersburg, 6, 541. [in Russian].

3. State Archive of the Russian Federation, p. 109, op. 180, file no. 104, p. 1. [in Russian].

4. State Archive of the Russian Federation, p. 109, op. 200, file no. 229, p. 13-35. [in Russian].

5. Dolgorukov, I. M. (1997). Kapishche moyego serdtsa [The temple of my heart]. Moscow: Science. [in Russian].

6. Dolgorukov, I. M. (2004). Povest o rozhdenii moyem, proiskhozhdenii i vsey zhizni [The story of my birth, origin and all my life]. St. Petersburg: Science, 1. [in Russian].

7. Durasov, V. (1912). Duelnyy kodeks [Dueling Code]. St. Petersburg. [in Russian].

8. Duel Pushkina s Dantesom-Gekkerenom. Podlinnoye voyenno-sudnoye delo 1837 goda [Duel of Pushkin with Dantes-Heeckeren. Genuine military court case of 1837] (1900). St. Petersburg. [in Russian].

9. Zayonchkovsky, P. A. (1973). Samoderzhaviye i russkaya armiya na rubezhe XIX-XX stoletiy [Autocracy and the Russian army at the turn of the XIX-XX centuries. Moscow: Thought. [in Russian].

10. Zapiski Sergeya Grigoryevicha Volkonskogo (dekabrista) [Notes of Sergei Grigorievich Volkonsky (Decembrist)] (1901). St. Petersburg. [in Russian].

11. Lermontovskaya entsiklopediya [Lermontov Encyclopedia] (1981). Moscow: Soviet Encyclopedia. [in Russian].

12. Livenson (1900). Poyedinok v zakonodatelstve i nauke [A duel in law and science]. St. Petersburg. [in Russian].

13. Lotman, Yu. M. (2011). Besedy o russkoy kulture: Byt i traditsii russkogo dvoryanstva (XVIII - nachalo XIX veka) [Conversations about Russian culture: Life and traditions of the Russian nobility (XVIII-early XIX century)]. St. Petersburg: Art-SPB. [in Russian].

14. Manifest o poyedinkakh [Manifesto on duels] (1830). Polnoye sobraniye zakonov Rossiyskoy imperii. Sobr. 1-ye [Complete collection of laws of the Russian Empire. Sobr. 1st.] St. Petersburg, 22, 843. [in Russian].

15. Markov, A. L. (1999). Poyedinki v russkoy armii. [Fights in the Russian army]. Novyy chasovoy. Russkiy voyenno-istoricheskiy zhurnal [New sentry. Russian military history journal], 8-9, 234. [in Russian].

16. Marenko, N. Yu. (2019). Pravyla o razbyratelstve ssor, sluchayushchykhsya v ofytserskoy srede: znachenye y posledstvyya yzmenenyya duelnoho zakonodatelstva $v 1894 \mathrm{~h}$. [Rules on the consideration of quarrels occurring in the officer environment: the significance and consequences of changes in duel legislation in 1894] Visnyk Kharkivskoho natsionalnoho universytetu. Seriya Istoriya [Bulletin of Kharkiv National University. History Series], 56, 81-82. [in Russian].

17. Patent o poyedinkakh i nachinanii ssor [Patent on duels and starting quarrels] (1830). Polnoye sobraniye zakonov Rossiyskoy imperii. Sobr. 1-e [Complete collection of laws of the Russian Empire. Sobr. 1st]. St. Petersburg, 5, 263. [in Russian].

18. Pravila o razbiratelstve ssor, sluchayushchikhsya v ofitserskoy srede [Rules for the investigation of quarrels that occur in the officer environment] (1898). Polnoye sobraniye zakonov v Rossiyskoy imperii [Complete collection of laws in the Russian Empire]. St. Petersburg, 14, 257-258. [in Russian].

19. Ruzhitskaya, I. V. (2015). Zakonodatelnaya deyatelnost v tsarstvovaniye imperatora Nikolaya I [Legislative activity during the reign of Emperor Nicholas I]. Moscow; St. Petersburg: Institute of Russian History RAS; Center for Humanitarian Initiatives. [in Russian].

20. Russkaya starina [Russian antiquity] (1908). Duel Erasi s Mellerom-Zakomelskim (Iz vospominaniy starogo gusara) [Duel of Erasi with Meller-Zakomelsky (From the memoirs of an old hussar)], 134, 598-603. [in Russian].

21. Russkiye ugolovnyye protsessy [Russian criminal trials] (1866). St. Petersburg, 1 . [in Russian].

22. Russkiye ugolovnyye protsessy [Russian criminal trials] (1867). St. Petersburg, 2. [in Russian].

23. Suvorin, A. (1913). Duelnyy kodeks [Duel code]. St. Petersburg. [in Russian].

24. Ulozheniye o nakazaniyakh ugolovnykh i ispravitelnykh [Code of penalties and penalties] (1845). St. Petersburg. [in Russian].

25. Fokkerodt, I. G. (1874). Rossiya pri Petre Velikom [Russia under Peter the Great]. Moscow. [in Russian].

26. Shendzikovsky, I. A. (1885). Konspekt lektsiy po istorii russkogo voyenno-ugolovnogo zakonodatelstva [Lecture notes on the history of Russian military criminal legislation]. St. Petersburg. [in Russian]. 